\title{
CITED2 Signals through Peroxisome Proliferator-Activated Receptor- $\gamma$ to Regulate Death of Cortical Neurons after DNA Damage
}

\author{
Yasmilde Rodriguez Gonzalez, ${ }^{1}$ Yi Zhang, ${ }^{1}$ Doreh Behzadpoor, ${ }^{1}$ Sean Cregan, ${ }^{2}$ Simon Bamforth, ${ }^{3}$ Ruth S. Slack, ${ }^{1}$ and \\ David S. Park ${ }^{1}$ \\ ${ }^{1}$ Ottawa Health Research Institute, Neuroscience Group, Ottawa, Ontario, Canada K1H 8M5, ${ }^{2}$ Robarts Research Institute, London, Ontario, Canada N6A \\ 5K8, and ${ }^{3}$ Department of Cardiovascular Medicine, University of Oxford, Oxford OX3 7BN, United Kingdom
}

\begin{abstract}
DNA damage is an important initiator of neuronal apoptosis and activates signaling events not yet fully defined. Using the camptothecininduced DNA damage model in neurons, we previously showed that cyclin D1-associated cell cycle cyclin-dependent kinases (Cdks) $(\mathrm{Cdk} 4 / 6)$ and $\mathrm{p} 53$ activation are two major events leading to activation of the mitochondrial apoptotic pathway. With gene array analyses, we detected upregulation of Cited2, a CBP (cAMP response element-binding protein-binding protein)/p300 interacting transactivator, in response to DNA damage. This upregulation was confirmed by reverse transcription-PCR and Western blot. CITED2 was functionally important because CITED2 overexpression promotes death, whereas CITED2 deficiency protects. Cited2 upregulation is upstream of the mitochondrial death pathway (BAX, Apaf1, or cytochrome $c$ release) and appears to be independent of p53. However, inhibition of the Cdk4 blocked Cited 2 induction. The Cited 2 prodeath mechanism does not involve Bmi-1 or p53. Instead, Cited 2 activates peroxisome proliferator-activated receptor- $\gamma(\operatorname{PPAR} \gamma)$, an activity that we demonstrate is critical for DNA damage-induced death. These results define a novel neuronal prodeath pathway in which Cdk4-mediated regulation of Cited 2 activates PPAR $\gamma$ and consequently caspase.
\end{abstract}

Key words: Cited2; PPAR $\gamma$; Cdk4; DNA damage; cortical neurons; camptothecin

\section{Introduction}

DNA damage in neurons is acknowledged as an important component of neuronal disease and injury. The pathways that regulate neuronal DNA damage-induced death converge on the classical intrinsic apoptotic pathway. For example, we showed that death induced by the DNA-damaging agent camptothecin, a topoisomerase I inhibitor, is mediated by BAX translocation to mitochondria, cytochrome $c$ (cyt $c$ ) release, and caspase- 3 activation (Stefanis et al., 1999; Keramaris et al., 2000).

Several major proapoptotic signals have been shown to precede this conserved mitochondrial pathway of death after DNA damage. For example, p53 regulates death, at least in part, by modulating prodeath $\mathrm{Bcl} 2$ members such as Puma (Keramaris et al., 2003; Sedarous et al., 2003; Aleyasin et al., 2004; Cregan et al., 2004).

Another signal, regulated independent of $\mathrm{p} 53$, is the activation of abnormal cell cycle signals. Accumulating evidence indicates that inappropriate activation of cell cycle cyclin-dependent ki-

\footnotetext{
Received Aug. 20, 2007; revised April 7, 2008; accepted April 20, 2008.

This work was supported by grants from the Canadian Institutes of Health Research, Heart and Stroke Foundation of Ontario (HSFO), Canadian Stroke Network, and Centre for Stroke Recovery (D.S.P.). Y.R.G. was supported by grants from Ontario Graduate Scholarship in Science and Technology and Ontario Graduate Scholarship. D.S.P. is an HSFO Career Investigator. We thank Dr. Shoumo Bhattacharya for the CITED2 transgenic mice and Cited2-expressing plasmids. We thank Dr. V. Krishna K. Chatterjee for his kind donation of the DNPPAR $\gamma$ construct.

Correspondence should be addressed to David S. Park, Ottawa Health Research Institute, 451 Smyth Road, Room 2444, 0ttawa, Ontario, Canada K1H 8M5. E-mail: dpark@uottawa.ca.

DOI:10.1523/JNEUROSCI.1014-08.2008

Copyright $\odot 2008$ Society for Neuroscience $\quad$ 0270-6474/08/285559-11\$15.00/0
}

nases (Cdks) lead to neuronal death. For example, we previously showed that cyclin D1/Cdk4 is activated and required for death after $\beta$-amyloid toxicity, delayed ischemic insult, and DNA damage (Park et al., 1998; Giovanni et al., 2000; Ghahremani et al., 2002; Rashidian et al., 2005). The manner by which this occurs is not completely clear. In models of DNA damage, we showed that cyclin D1/Cdk4 activation is regulated by a Chk1/cdc25a pathway (Zhang et al., 2006). Cdk4 then phosphorylates the tumor suppressor retinoblastoma $(\mathrm{Rb})$ protein leading to E2F transactivation (Park et al., 1998, 2000). Although these findings provide a skeletal structure to death regulation induced by cell cycle signaling and DNA damage, additional players are likely involved.

To this end, we undertook a gene array study to examine for differentially expressed genes from embryonic cortical neurons exposed to camptothecin (campto) (our unpublished data). One of the genes significantly upregulated was Cited2, a CBP (cAMP response element-binding protein-binding protein)/p300 interacting transactivator. Cited2 was first identified as a transcriptional coactivator expressed in the nucleus (Bhattacharya et al., 1999). Cited 2 has a critical role in development and its deficiency is embryonic lethal. Knock-out (KO) embryos exhibit cardiac malformations, adrenal agenesis, neural crest defects, and exencephaly (Bamforth et al., 2001). Cited 2 is also a target/negative regulator of hypoxia-inducible factor (HIF) (Bhattacharya et al., 1999; Freedman et al., 2003). Additionally, Cited 2 promotes proliferation at least in part via activation of expression of the polycomb-group genes Bmi-1 (Kranc et al., 2003), negative reg- 
ulator of the ink4a-ARF locus. Finally, Cited 2 can act as a ligand independent activator of peroxisome proliferator-activated receptors (PPARs) $\alpha$ and $\gamma$ (Tien et al., 2004). PPARs are nuclear receptors with transcriptional activity that have been implicated in a wide range of biological processes including cell growth, lipid homeostasis, angiogenesis, and neuronal apoptosis.

The main goal of this research project, then, was to elucidate the role and mechanism of action of Cited 2 in neuronal apoptosis induced by DNA damage. We show that Cited 2 is part of the cell cycle pathway and acts to promote death through activation of PPAR $\gamma$. This defines a novel pathway by which abnormal cell cycle activation regulates neuronal death.

\section{Materials and Methods}

Primary cultures and drug treatments. Cortical neurons were dissected from embryonic day 14 (E14) to E15 mouse embryos, plated at 1.25$1.8 \times 10^{6}$ cells $/ \mathrm{ml}$, and cultured in supplemented Neurobasal media (Invitrogen) at $37^{\circ} \mathrm{C}$ and $5 \% \mathrm{CO}_{2}$. After $2-4 \mathrm{~d}$ in vitro (DIV), cells were treated with 1 or $10 \mu \mathrm{M}$ camptothecin and/or CDK inhibitor [ $1 \mu \mathrm{M}$ flavopiridol (Stefanis et al., 1999)], caspase inhibitor [50 $\mu \mathrm{M}$ BocAsp (OMe)-fluoromethyl ketone (BAF) (Keramaris et al., 2000)], mixed lineage kinase (MLK) inhibitor [200 nM CEP11004 (Ghahremani et al., 2002)], PPAR $\gamma$ inhibitor [10-30 $\mu \mathrm{M}$ 2-chloro-5-nitrobenzanilide (GW9662) (Leesnitzer et al., 2002)], or PPAR $\gamma$ agonist [20-50 $\mu \mathrm{M}$ ciglitazone (Willson et al., 1996)].

Transgenic mice. All transgenic mice used were in a C57BL/6J background. Cortical neurons from each embryo derived from heterozygous crosses were dissected and plated individually. Embryos were genotyped by PCR using specific primers for wild-type (WT) and KO alleles. Embryos from Cited 2 crosses were genotyped using the following primers and program: 247 bp WT product: upper, 5' -aaaggcgctaaggatagacac- $3^{\prime}$; lower, $5^{\prime}$-atactgaggtccctggcac- $3^{\prime} ; 372$ bp KO product: upper, $5^{\prime}$-ctacccggtagaattgacctg- $3^{\prime}$; lower, $5^{\prime}$-tgctgtaagaccttcttggc- $3^{\prime} ;$ PCR program: $94^{\circ} \mathrm{C}$ for $10 \mathrm{~min} ; 15 \mathrm{cycles}$ of $95^{\circ} \mathrm{C}$ for $30 \mathrm{~s}, 30 \mathrm{~s} 67.5-0.5^{\circ} \mathrm{C} /$ cycle, $72^{\circ} \mathrm{C}$ for $45 \mathrm{~s}$; 15 cycles of $95^{\circ} \mathrm{C}$ for $30 \mathrm{~s}, 60^{\circ} \mathrm{C}$ for $30 \mathrm{~s}$, and $72^{\circ} \mathrm{C}$ for $45 \mathrm{~s}$. This was followed by $72^{\circ} \mathrm{C}$ for $10 \mathrm{~min}$. Embryos from p53, BAX, and Apaf- 1 transgenic mice crosses were genotyped as previously described (Cregan et al., 1999; Fortin et al., 2001; Aleyasin et al., 2004).

Semiquantitative reverse transcription-PCR. Total RNA was extracted/ purified using TriPure isolation reagent (Trizol) per the manufacturer's protocols (Invitrogen). Fifty nanograms of total RNA were used for the cDNA synthesis and gene amplification reactions using SuperScript One-Step with Platinum Taq from Invitrogen. cDNA synthesis was performed at $48^{\circ} \mathrm{C}$ for $45 \mathrm{~min}$, followed by a $2 \mathrm{~min}$ initial denaturation step at $94^{\circ} \mathrm{C}$. This was followed by 30 cycles (Noxa, HIF1- $\alpha$, cyt $c$ ), 26 cycles (PUMA), or 25 cycles (Cited2, PPAR $\gamma, \mathrm{Bmi}-1, \mathrm{~S} 12)$ at $94^{\circ} \mathrm{C}$ for $30 \mathrm{~s}$, melting temperature $(\mathrm{Tm})\left({ }^{\circ} \mathrm{C}\right)$ for $30 \mathrm{~s}$, and $72^{\circ} \mathrm{C}$ for $1 \mathrm{~min}$. Targeting primers were as follows: for Cited2, $5^{\prime}$-tagggcagcggaggaaaagaa- $3^{\prime}$ and $5^{\prime}$-ccctcgccgtagtgtatgtgctc- $3^{\prime}\left(\mathrm{Tm}, 60^{\circ} \mathrm{C}\right)$; for Bmi-1, $5^{\prime}$-agagcagattggatcggaaa- $3^{\prime}$ and $5^{\prime}$-gactgggcaaacaggaagag- $3^{\prime}\left(\mathrm{Tm}, 58^{\circ} \mathrm{C}\right)$; for PPAR $\gamma$, $5^{\prime}$-aggcgagggcgatcttgacag- $3^{\prime}$ and $5^{\prime}$-agggcttccgcaggttttgag- $3^{\prime}\left(\mathrm{Tm}, 57^{\circ} \mathrm{C}\right.$ ); for PUMA, $5^{\prime}$-cctcagccctccetgtcaccag- $3^{\prime}$ and $5^{\prime}$-ccgccgctcgtactgcgcgttg- $3^{\prime}$ $\left(\mathrm{Tm}, 55^{\circ} \mathrm{C}\right)$; for HIF1- $\alpha, 5^{\prime}$-tgctcatcagttgccacttc- $3^{\prime}$ and $5^{\prime}$-cttccacgttgctgacttga- $3^{\prime}\left(\mathrm{Tm}, 59^{\circ} \mathrm{C}\right)$; for cytochrome $c, 5^{\prime}$-ccaaatctccacggtctgtt- $3^{\prime}$ and $5^{\prime}$-gtctgccctttctcccttct- $3^{\prime}\left(\mathrm{Tm}, 59^{\circ} \mathrm{C}\right)$. Products were resolved on a $2 \%$ agarose (Invitrogen)-ethidium bromide gel, and correct band for Cited2, Bmi-1, PPAR $\gamma$, HIF1- $\alpha$, and cyt $c$ were processed by densitometry. Transcript levels were normalized against $\mathrm{S} 12$ signals and results were reported as times fold increase in reference to control values (untreated control for each individual experiment) or as relative mRNA level (normalized value). Data are presented as mean \pm SEM of at least three independent experiments.

Quantitative reverse transcription-PCR. Twenty nanograms of RNA was used in one-step SYBR green reverse transcription (RT)-PCR as per manufacturer's instructions (QuantiTect; QIAGEN). RT-PCR was performed on a Chromo4 system (MJ Research/Bio-Rad) and changes in Cited 2 mRNA were determined by the $\Delta(\Delta \mathrm{Ct})$ method using S12 transcript for normalization. PCRs exhibited high amplification efficiency $(>90 \%)$ and the specificity of PCR products was confirmed by sequenc- ing. Data are reported as fold increase in mRNA levels in campto-treated samples relative to corresponding untreated control cells and expressed as mean $\pm \operatorname{SEM}(n=4$ for each genotype).

SDS-PAGE and Western analysis. Cells were harvested after wash with cold PBS by scraping in $62.5 \mathrm{~mm}$ Tris- $\mathrm{HCl}, 2 \% \mathrm{w} / \mathrm{v}$ SDS, $10 \%$ glycerol, 50 $\mathrm{mm}$ dithiothrietol, and $0.1 \% \mathrm{w} / \mathrm{v}$ bromophenol blue, heated at $95-100^{\circ} \mathrm{C}$ for $5 \mathrm{~min}$, and then resolved on 7.5, 10, or 20\% SDS-PAGE. Transference was done to polyvinylidene difluoride membranes (PolyScreen; PerkinElmer Life and Analytical Sciences) that were then incubated in $1 \%$ casein-Tris-buffered saline (TBS) for blocking. Primary antibodies were diluted in $5 \%$ bovine serum albumin (BSA)/TBS as follows: antiCITED2, 1:500 (Novus Biologicals; JA22); anti-PPAR $\gamma, 1: 200$ (Santa Cruz; H-100:sc-7196); anti- $\beta$-actin, 1:3000 (Sigma-Aldrich); anticytochrome $c, 1: 2000$ (BD Biosciences Pharmingen); anti-OxPhoscomplex I subunit, 1:1000 (Invitrogen); anti-PPAR $\alpha$, 1:150 (Santa Cruz); and anti-HIF1- $\alpha$, 1:500 (Cayman Chemical). Secondary antibodies [goat anti-mouse or anti-rabbit IgG(H_L) HRP conjugate (Bio-Rad)] were all used at 1:3000 in 3\% BSA in $136 \mathrm{~mm} \mathrm{NaCl}, 2.68 \mathrm{~mm} \mathrm{KCl}, 10.14$ $\mathrm{mm} \mathrm{Na}_{2} \mathrm{HPO}_{4}, 1.76 \mathrm{~mm} \mathrm{KH}_{2} \mathrm{PO}_{4}, \mathrm{pH}$ 7.4, and $0.1 \%$ Tween 20 (PBS/T). Immunoreactivity was detected using Western blot chemiluminescence reagent system (PerkinElmer Life and Analytical Sciences). Results were processed by densitometry. Protein levels were normalized against $\beta$-actin signals, and results were reported as times fold increase in reference to control values (untreated control for each individual experiments) or as relative protein level (normalized value). Data are presented as mean \pm SEM of at least three independent experiments.

Transient transfection by calcium phosphate. Seventy-two to $96 \mathrm{~h}$ after plating, cortical neurons were transiently transfected using calcium phosphate coprecipitation protocol as described previously (Xia et al., 1996; Zhang et al., 2006). Cortical neurons were cotransfected with cytomegalovirus (CMV) promoter-driven green fluorescent protein (GFP)-expressing plasmid ( $3 \mu \mathrm{g}$ ) and an empty vector (pcDNA3) or Cited2-expressing vector $(6 \mu \mathrm{g})$, generously donated by Dr. Shoumo Bhattacharya (The Wellcome Trust Centre for Human Genetics, Oxford, UK). Twenty-four hours after transfection, DNA damage was induced by adding $10 \mu \mathrm{M}$ campto and cells were incubated for $21 \mathrm{~h}$. Cells were then fixed in $4 \%$ paraformaldehyde, $125 \mathrm{~mm}$ sodium dihydrogen phosphate, $125 \mathrm{~mm}$ disodium hydrogen phosphate, and $14 \%$ picric acid for $30 \mathrm{~min}$ at room temperature and washed with PBS. Transfected cells were identified by green fluorescence and integrity of the nucleus was analyzed by $0.25 \mathrm{~g} / \mathrm{ml}$ Hoechst 33342 staining (10 min at room temperature; SigmaAldrich). At least 250 GFP-positive cells per treatment were counted. Percentage survival was calculated as GFP-expressing live/GFPexpressing total number of neurons. Results are presented as mean \pm SEM of three replicas per treatment.

Transient transfection with Lipofectamine. Neuronal cultures were transfected using Lipofectamine 2000 (Invitrogen) at a ratio of $1.3 \mu \mathrm{g}$ of DNA to $1 \mu \mathrm{l}$ of Lipofectamine/well. Briefly, neurons were cotransfected with $0.3 \mu \mathrm{g}$ of reporter vector (CMV promoter-driven GFP-expressing plasmid) and $1.0 \mu \mathrm{g}$ of empty (pcDNA3), Cited2-, or DNPPAR $\gamma$ expressing vector [ generously donated by Dr. Shoumo Bhattacharya and Dr. V. Krishna K. Chatterjee (Institute of Metabolic Science, Cambridge, UK), respectively]. Twenty-four hours after transfection, cells were treated with $10 \mu \mathrm{M}$ campto, $20 \mu \mathrm{M}$ GW9662, $40 \mu \mathrm{M}$ ciglitazone, alone or in specified combinations, and incubated for $21 \mathrm{~h}$. Cells were then fixed and processed accordingly.

Viral infection. Adenoassociated virus (AAV) expressing a kinase-dead [dominant-negative (DN)] form of Cdk4 was obtained as previously described (Rashidian et al., 2005). Cortical neurons were exposed to 150 multiplicity of infection (MOI) units of AAV at the time of plating. Six to 7 DIV after infection, cells were exposed to campto as described above, and total mRNA or protein was extracted. Samples were used to detect Cited2 levels by RT-PCR and Western blot as previously stated.

Cell survival assessment. Cells were lysed in $150 \mu \mathrm{l}$ of cell lysis buffer (0.1× PBS, pH 7.4, 0.5\% Triton X-100, 2 mM $\mathrm{MgCl}_{2}, 0.5 \%$ cetylmethylammonium bromide). Nuclei were evaluated under phase microscopy and healthy ones were counted (at least 150 nuclei for nontreated control wells). Percentage survival was calculated as the remaining number of live nuclei in campto-treated $(12,16,20 \mathrm{~h})$ compared with untreated 
A

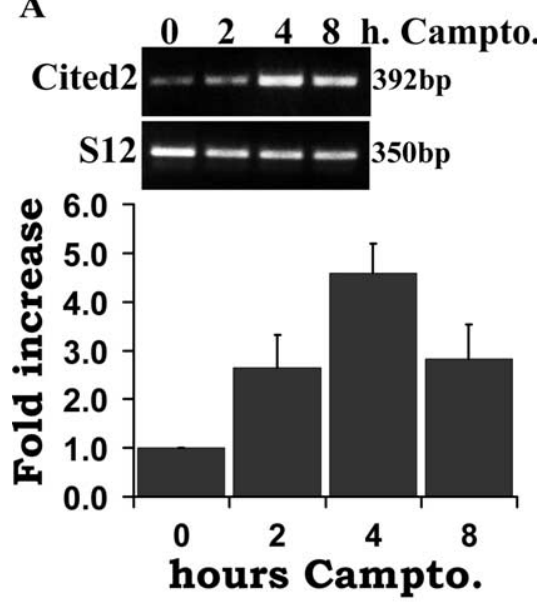

B
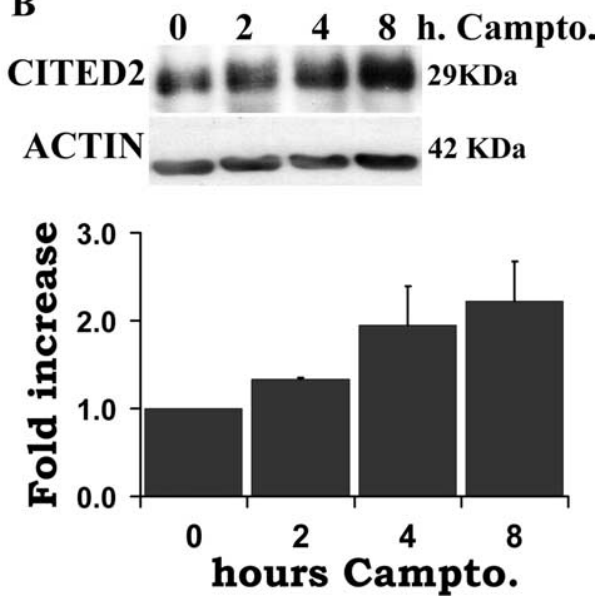

Figure 1. Cited2 mRNA and protein levels are upregulated after DNA damage. Total mRNA or protein was extracted from cortical neurons treated for different times with $10 \mu \mathrm{m}$ campto and subjected to either RT-PCR $(\boldsymbol{A})$ or Western blot $(\boldsymbol{B})$. Densitometry of all signals was performed and Cited 2 signal was normalized to $S 12(\boldsymbol{A})$ and actin $(\boldsymbol{B})$, respectively. Data are presented as fold increase relative to nontreated sample for each separate experiment. Each bar represents the mean \pm SEM from at least three independent experiments.

control $(0 \mathrm{~h} ; 100 \%)$. Data are presented as mean \pm SEM of at least three independent experiments.

PPAR $\gamma$ reporter experiments. TransLucent PPAR $\gamma$ reporter vectors from Panomics (LR0066) were used. Embryonic cortical neurons from CD1 WT mice or transgenic Cited2 littermates were used. Three days in vitro after plating, cells were cotransfected with CMV- $\beta$-galactosidaseand PPAR $\gamma$ responsive element (PPRE)-luciferase-expressing plasmids as described above for Lipofectamine transfection. Twenty-four hours after, cells were then exposed to $10 \mu \mathrm{M}$ campto and or $1 \mu \mathrm{M}$ flavopiridol. At $0-4 \mathrm{~h}$ after treatment, cells were collected and lysed with $130 \mu \mathrm{l}$ of cell culture lysis reagent (Promega). For coexpression of Cited 2 and PPREluciferase, transfection was made using $0.3 \mu \mathrm{g}$ of $\mathrm{CMV}-\beta$-galactosidase and $1 \mu \mathrm{g}$ of each Cited2- and PPRE-luciferase-expressing plasmids for a total of $2.3 \mu \mathrm{g}$ of DNA/1 $\mu$ l of Lipofectamine. Samples were assayed in triplicates for luciferase and $\beta$-galactosidase activity as previously described (Fortin et al., 2001). Luciferase activity signals were standardized using $\beta$-galactosidase activity values and results were presented either as relative PPAR $\gamma$ activity (luciferase/ $\beta$-galactosidase) or as fold increase in reference to control values (untreated control for each individual experiment, $0 \mathrm{~h}$ ). Data are presented as mean \pm SEM of three independent experiments.

Caspase activity. After $2 \mathrm{DIV}$, cells were treated with $10 \mu \mathrm{M}$ campto and/or $20 \mu \mathrm{M}$ GW9662, as described above. Total protein was extracted in $1 \mathrm{~mm} \mathrm{KCl,} 10 \mathrm{~mm}$ HEPES, $1.5 \mathrm{~mm} \mathrm{MgCl}_{2}, 1 \mathrm{~mm}$ DTT, $1 \mathrm{~mm}$ PMSF, $10 \%$ glycerol, protease inhibitor mixture (Roche) as described previously (O'Hare et al., 2000). Each sample was analyzed in three replicas of $5 \mu \mathrm{g}$ each. Protein was incubated with Z-DEVD-AFC (Invitrogen) in caspase assay buffer [25 mm HEPES, $10 \mathrm{~mm}$ DTT, 10\% sucrose, 0.1\% CHAPS (3-[(3-cholamidopropyl)dimethylammonio]-1-propanesulfonate), 15 $\mu \mathrm{M}$ Z-DEVD-AFC] and fluorescence at $505 \mathrm{~nm}$ was measured at different time points ( $30 \mathrm{~min}$ to $2 \mathrm{~h}$ ), using an excitation wavelength of $400 \mathrm{~nm}$. Readings were made using a PerkinElmer Life and Analytical Sciences LS 50B Luminescence spectrometer with a slit width of 5 and $1 \mathrm{~s}$ integration time. Fluorescence versus time was plotted for each replica and the slope of the curve (linear regression) was used as cleavage activity value (caspase activity). Data are presented as mean \pm SEM of four independent experiments.

Cytochrome c inmmunocytochemistry. After 2 DIV, cortical neurons from CD1 WT embryos or littermate embryos derived from heterozygous Cited 2 mice crosses were treated with $10 \mu \mathrm{M}$ campto or/and 20 $\mu \mathrm{M}$ GW9662 for $12 \mathrm{~h}$, fixed as described above, and stained with cyt $c$ antibody (BD Biosciences Pharmingen), followed by Hoechst 33258 staining. At least 100 cells per replica were assessed by immunofluorescence and neurons positive for punctate cyt $c$ were counted. Data are presented as percentage mitochondrial cyt $c$ (percentage of neurons positive for punctate cyt $c$ ). The bars represent the mean \pm SEM from three independent experiments or embryos of each specified genotype.

Immunoprecipitation. Cortical neurons $\left(\sim 20 \times 10^{6}\right.$ cells $)$ were harvested in lysis buffer (50 mm Tris- $\mathrm{HCl}, \mathrm{pH} 7.4,100 \mathrm{~mm} \mathrm{NaCl}, 1 \mathrm{~mm}$ EDTA, $1 \mathrm{~mm}$ DTT, and 0.2\% NP-40) supplemented with protease inhibitors. Immunoprecipitations (IPs) were performed through incubation of anti-Cited2 antibody (JA22) with lysates overnight followed by incubation with anti-mouse Ig IP beads (eBiosciences) at $4^{\circ} \mathrm{C}$ for $2 \mathrm{~h}$. The beads were washed three times by lysis buffer without protease inhibitors.

\section{Results}

Cited2 signals death of cortical neurons after DNA damage

Our initial gene array screen suggested that Cited 2 might be upregulated after DNA damage treatment. To test this, we first determined whether Cited2 message was upregulated after campto treatment by RT-PCR. As shown in Figure $1 \mathrm{~A}$, induction of Cited 2 message was detectable as early as $2 \mathrm{~h}$ after initiation of camptothecin treatment and reached a maximum $(\sim 4.5$-fold $)$ induction at $4 \mathrm{~h}$. We next determined whether an increase in message was also associated with increased protein levels. Consistent with an increase in message, CITED2 protein was also induced with an increase detectable as early as $2 \mathrm{~h}$ ( $p$ value, 0.036). Protein levels were still induced $8 \mathrm{~h}$ after DNA damage treatment (Fig. $1 B$ ).

The early induction of Cited 2 suggested it might be functionally relevant for death. This is particularly important because, in this model, we have previously shown that the commitment point for death occurs 6-8 h after treatment (Morris et al., 2001). To test the functional importance of Cited2, we determined the effect of Cited2 overexpression on neuronal survival either with or without DNA damage insult. We first delivered Cited2 by calcium phosphate transfection. Importantly, in this initial experiment, there was more death in neurons expressing Cited2 when compared with GFP control either basally (42.4 vs $27.5 \%$ ) or with campto treatment (64 vs $48.1 \%$ ) (Fig. $2 A$ ). To confirm this, we subsequently performed three independent experiments using Lipofectamine carrier. This was done to insure that any results were not necessarily attributable to the delivery method. We obtained similar results (Cited2 vs GFP, basally 37.2 vs $23.6 \%$, or with campto treatment, 74.7 vs $55.8 \%$ ) (see Fig. $6 C$ ). This indicates that Cited 2 is sufficient to induce death. To address whether Cited 2 was necessary for neuronal death, we cultured cortical neurons from Cited2-deficient or heterozygous and WT littermate controls. As shown in Figure 2B, the absence of Cited2 in neurons confers significant resistance to the genotoxic insult. Deficiency by itself delays, but does not prevent, death. Together, these results indicate that upregulated Cited2 contributes to death of neurons after DNA damage.

\section{DNA damage-Cited2 induction is upstream of the} mitochondrial death pathway but independent of $\mathrm{p} 53$ We next wanted to determine the factors that regulated Cited2 induction. The early induction of Cited2 suggested that its regulatory pathways would also act early. Indeed, we previously showed caspase activation occurs later at $\sim 6-8 \mathrm{~h}$ after initiation 

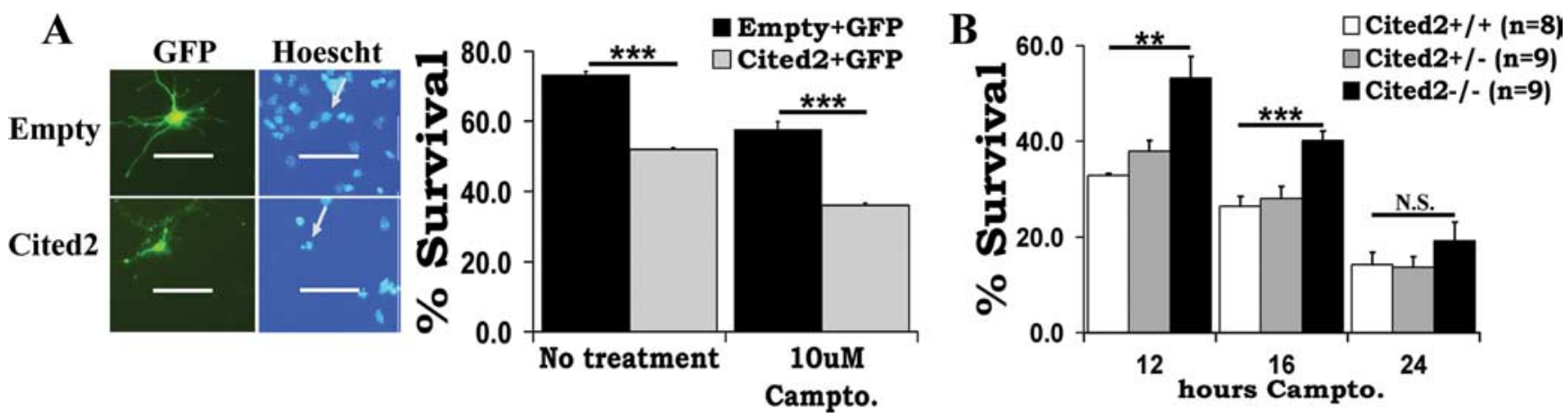

Figure 2. Cited2 overexpression promotes neuronal death, whereas Cited 2 deficiency promotes survival after DNA damage. $\boldsymbol{A}$, Seventy-two to $96 \mathrm{~h}$ after plating, cortical neurons were transiently cotransfected with empty pCDNA3 or pcDNA3-Cited 2 and pEGPF using calcium phosphate. Twenty-four hours after, $10 \mu \mathrm{m}$ campto was added and incubated for $21 \mathrm{~h}$ followed by fixation and Hoechst 33258 staining. Left, Photomicrographs of alive or dead cortical neurons under green fluorescence, showing GFP-transfected neurons and Hoechst-stained nuclei. At least $250 \mathrm{GFP}$-positive nuclei per treatment were assessed. Scale bar, $50 \mu \mathrm{m}$. Right, Quantitation of death induced by Cited2 expression. Percentage survival was calculated as percentage of live over total GFP-expressing neurons. Data represent the mean \pm SEM from three replicas/treatment. ${ }^{* * *} p<0.001$. $B$, Cortical neurons from littermate embryos derived from multiple heterozygous Cited 2 mice crosses were cultured independently and treated with $10 \mu \mathrm{m}$ campto for 12,16 , or $24 \mathrm{~h}$ as indicated. Cells were lysed and the number of surviving neurons was evaluated. Percentage survival was calculated as the number of live neurons in campto-treated compared with untreated control for each embryo. Each bar represents the mean \pm SEM from $n$ embry0s as indicated. ${ }^{* *} p<0.01 ;{ }^{* * *} p<0.001 ;$ N.S., no significant difference.

of campto treatment and coincides with death commitment (Keramaris et al., 2000; Morris et al., 2001). This suggested that the conserved mitochondrial pathway acts downstream of Cited2. Bax and Apaf-1 are both critical for neuronal death and caspase activation induced by DNA damage (Xiang et al., 1998; Fortin et al., 2001). Importantly, deficiency of either gene did not alter the induction of Cited 2 consistent with the upstream nature of the Cited2 signal (Fig. 3A). Similarly, caspase inhibitor (BAF) treatment also did not inhibit Cited2 induction (Fig. 3B). To confirm whether Cited2 was upstream of the mitochondrial pathway of death, we examined the levels of mitochondrial cyt $c$ release after campto treatment in Cited2-deficient neurons compared with WT littermates. Cited2 deficiency significantly inhibits mitochondrial cyt $c$ release (Fig. $3 C$ ) after DNA damage. To ensure that the observed effects of Cited 2 deficiency were not attributable to basal differences in mitochondrial content between KO Cited 2 and WT neurons, we examined for levels of mitochondrial markers, cyt $c$ and OxPhos mitochondrial complex I subunit. As shown in Figure $3 D$, top, no significant differences were found in cyt $c$ message as measured by RT-PCR between the two genotypes. In addition, Western blot analyses also showed no differences in cyt $c$ and OxPhos mitochondrial complex I subunit, suggesting that Cited2-deficient neurons have mitochondria levels similar to WT cells (Fig. 3D, bottom). Together, these results indicate that Cited 2 induction is upstream of the conserved mitochondrial death pathway.

The c-Jun N-terminal kinase (JNK) pathway has also been implicated as important for DNA damage-induced death. We showed previously that the potent MLK inhibitor CEP11004 blocked the JNK/c-Jun pathway and protected neurons from death (Ghahremani et al., 2002). However, JNK inhibition also failed to significantly affect Cited 2 induction at early time points (Fig. $3 B$ ). In contrast, at later time points $(8 \mathrm{~h})$, there did appear to be some effect with JNK inhibition. Therefore, although there was some modulatory effect of the JNK pathway on Cited2 late induction, it did not appear to be the major pathway regulating Cited2.

We mentioned above the relevance of the p53 pathway as a required proapoptotic signal after DNA damage in neurons. p53 activation can be detected as early as $2 \mathrm{~h}$ (Morris et al., 2001), making it a possible candidate as a Cited 2 regulator. However, deficiency of p53 gene did not alter the induction of Cited 2 suggesting that the Cited 2 signal was independent of p53 (Fig. 3E).

\section{DNA damage-Cited 2 induction is regulated by $\mathrm{Cdk} 4$ activity}

One of the earliest signals that changes after exposure to DNA damaging agent is cyclin D1-associated activity. We previously showed that this pathway is activated as early as $0.5-1 \mathrm{~h}$ after DNA damage (Park et al., 1998). To test whether the Cdk pathway might be important, we first examined the effects of treatment with the potent Cdk inhibitor flavopiridol. This general Cdk inhibitor protects neurons from campto-induced death as well as blocks downstream targets of the Cdks such as the Rb protein (Park et al., 1997a). Importantly, flavopiridol treatment blocked the induction of Cited 2 mRNA (Fig. $4 A, C$ ) and protein (our unpublished data).

Because of potential nonspecific effects of flavopiridol, we also determined whether expression of a kinase-dead dominantnegative form of Cdk4 (DNCdk4), which we also reported blocks neuronal death (Ghahremani et al., 2002), inhibits induction of Cited2. DNCdk4 was targeted to the culture via viral-mediated delivery. As shown in Figure 4, $B$ and $C$, DNCdk4 expression also significantly blocked Cited 2 induction. Remarkably, unlike flavopiridol, DNCdk4 has no effect on basal Cited2 levels (no significant difference between untreated control and infected cells; $p$ value, 0.936). This suggests that Cdk4 specifically mediates the induction of Cited 2 under genotoxic conditions. The reason why flavopiridol affects basal levels of Cited 2 in addition to its induction is unknown but may be attributable to non-Cdk4-mediated effects (other Cdks, other nonspecific effects). Nevertheless, our results are consistent with the notion that $\mathrm{Cdk} 4$ is critical for the upregulation of Cited2 after camptothecin-induced DNA damage.

\section{Cited2-mediated death does not involve Bmi-1, p53, or HIF1- $\alpha$}

We next determine how Cited 2 may regulate death after DNA damage. Previous reports suggest that Cited2 stimulates proliferation by induction of Bmi-1 that in turn represses the INK4/ARF locus of cell cycle inhibitors (Kranc et al., 2003). We hypothesized that, in our model, Cited 2 would be a signal activated by Cdk 4 to ensure its own level of activation and that 
A
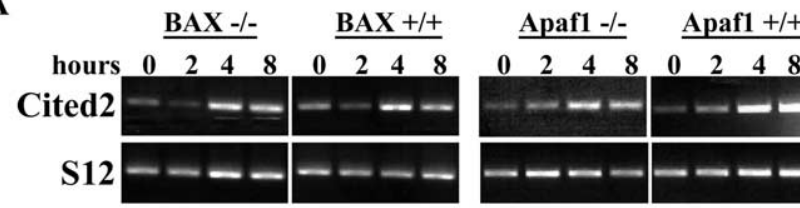

$392 \mathrm{bp}$

B

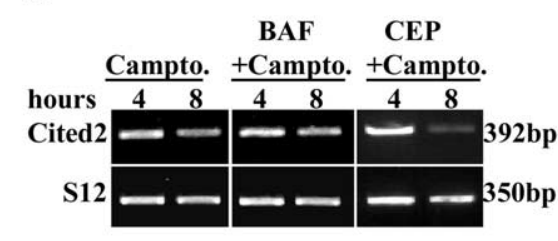

C

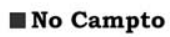

$\square$ 10uM Campto

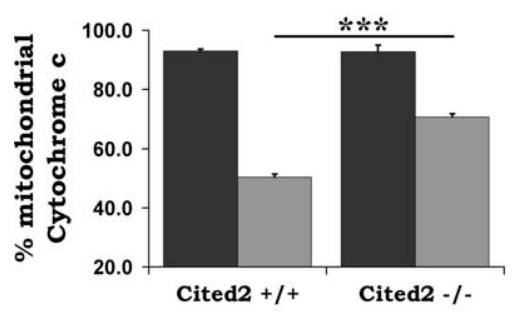

$\mathbf{E}$

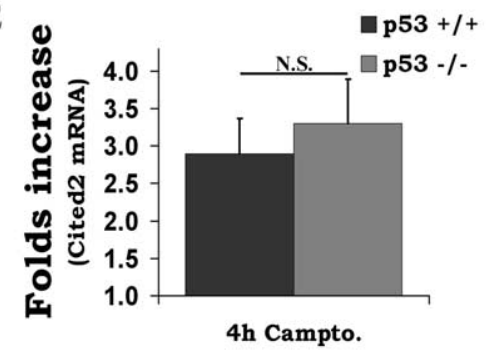

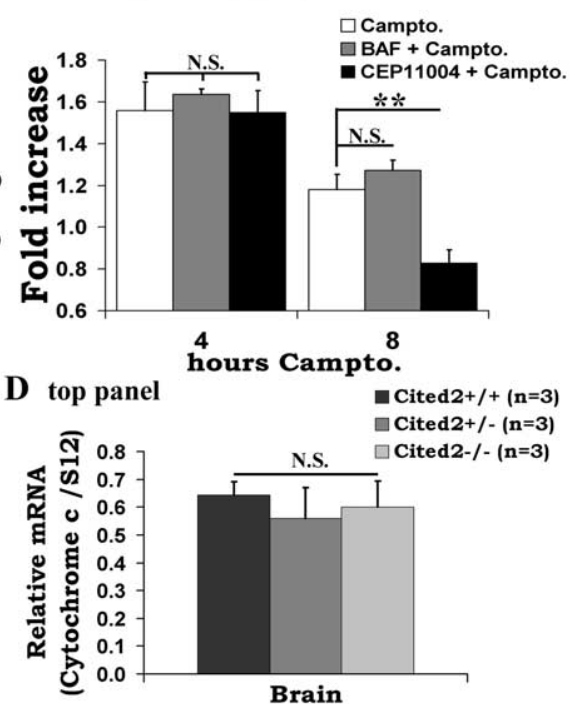

bottom panel

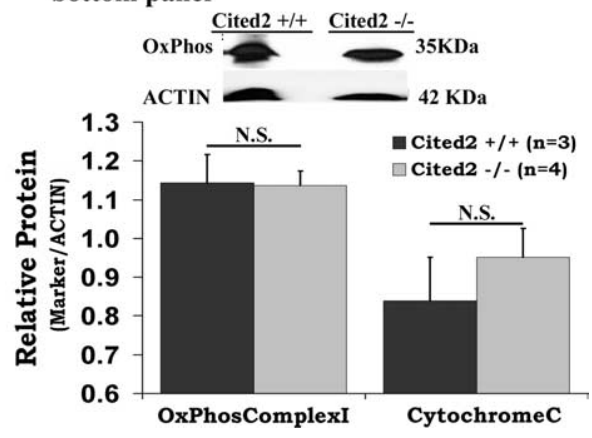

Figure 3. Cited2 early upregulation is upstream of the mitochondrial apoptotic pathway and upstream or independent of the JNKs and p53 pathways. A, BAX or Apaf-1 deficiency does not alter Cited2 upregulation. Cortical neurons derived from heterozygous breeding of BAX or Apaf-1 transgenic mice were cultured and treated with $10 \mu \mathrm{m}$ campto for 2,4 , and $8 \mathrm{~h}$ as indicated. Total RNA was extracted and subjected to RT-PCR for Cited2 transcript. Results from representative embryos are presented. $\boldsymbol{B}$, Caspases or JNK inhibition does not affect early Cited2 upregulation. Total mRNA was extracted from cortical neurons treated for the indicated times with campto and/or caspases inhibitor (50 $\mu \mathrm{m}$ BAF) or MLK inhibitor (200 nм CEP11004). Left, Results of one representative experiment. Right, Normalized densitometry data from at least three independent experiments. Each bar represents the mean \pm SEM. ${ }^{* *} p<0.01$; N.S., no significant difference. C, Cited2 deficiency inhibits mitochondrial cyt c release. Cortical neurons from littermate embryos derived from heterozygous Cited2 mice crosses were cultured as independent experiments and campto-treated for $12 \mathrm{~h}$, followed by fixation and cyt c/Hoechst 33258 staining. Quantitation is presented as percentage of neurons positive for punctate cyt $c$. Data represent the mean \pm SEM from three embryos of each specified genotype. ${ }^{* * *} p<0.001$. $\boldsymbol{D}$, Markers of mitochondria do not differ between Cited2 K0 and WT neurons. Total mRNA from brains (top) or protein from cortical neurons (bottom) derived from embryos from heterozygous Cited2 mice crosses were analyzed as indicated for mitochondrial markers by RT-PCR or Western blot. mRNA results are normalized to $S 12$ as control and Westerns are normalized to actin. Bars represent the mean \pm SEM from $n$ embryos. N.S., No significant difference. $E$, p53 deficiency does not alter Cited2 upregulation. WT or p53-deficient littermate cortical neurons were treated with $10 \mu \mathrm{m}$ campto for $4 \mathrm{~h}$. Total RNA was extracted and subjected to quantitative RT-PCR for Cited2 transcript. Quantitative data from four embryos of specified genotype are presented as fold increase compared with untreated control for each embryo. The bars represent the mean \pm SEM. N.S., No significant difference.

this would occur through Bmi-1 induction by Cited2. Indeed, our results using RT-PCR show that Bmi-1 message is slightly induced $(\sim 1.5$-fold) after DNA damage (Fig. $5 A)$. This also confirmed results in our original gene array screen (our unpublished data).

To test the hypothesis that Bmi-1 may be a downstream signal of Cited 2 to mediate death after DNA damage, Bmi-1 expression

levels were analyzed by RT-PCR in presence or absence of endogenous Cited2. However, no differences were observed between Cited2-deficient and WT neuronal cultures (Fig. 5A). This indicates that, although Bmi-1 message levels are changed after DNA damage, this is not relevant for a Cited2-induced pathway of death.

It has been reported that $\mathrm{p} 53$ is one major player in neuronal DNA damageinduced apoptosis (Morris et al., 2001; Aleyasin et al., 2004; Vaughn and Deshmukh, 2007). Additionally, we previously showed that there appears to be cross talk between Cdk4/6 and p53 apoptotic pathways (Morris et al., 2001). Here, we explored the possibility of Cited 2 being part of the cross talk mechanisms. To assess the consequences of Cited 2 deficiency on p53 activity, we looked at the profile of induction of two known p53 targets in our model: PUMA and Noxa (Aleyasin et al., 2004; Cregan et al., 2004), in the presence or absence of endogenous Cited2 (Fig. 5B). In this case, as well as with Bmi-1, Cited2 deficiency does not appear to inhibit the induction of these two genes when compared with WT littermates. This suggests that Cited 2 mechanism of death does not include p53 activation.

Cited 2 has also been reported to regulate and be regulated by HIF $1-\alpha$ (Bhattacharya and Ratcliffe, 2003; Freedman et al., 2003). Importantly, Cited2 deficiency has been shown to result in increased message of HIF1- $\alpha$-responsive genes in the heart (Yin et al., 2002). Interestingly, a recent report suggests that HIF1- $\alpha$ expression protects hippocampal neurons (HT22) against DNA damage (Aminova et al., 2005). Accordingly, we wanted to examine whether the protection conferred by Cited 2 deficiency was related to differences in HIF1- $\alpha$ levels. Using RT-PCR and Western blot, we looked at the basal levels of HIF1- $\alpha$ in the brain and cultured cortical neurons of embryos from Cited 2 heterozygous crosses. As shown in Figure 5C, top, we did not find any differences on HIF1- $\alpha$ transcript levels in the brain of $\mathrm{KO}$ versus WT embryos. Moreover, cortical neurons treated with DNA damage show decreased HIF1- $\alpha$ transcripts (our unpublished data). Interestingly, HIF1- $\alpha$ protein levels did not appear to differ either between Cited2 KO and WT littermates (Fig. 5C, bottom). These data suggest that Cited 2 deficiency is not protective simply because it leads to upregulation of basal HIF1- $\alpha$. This result would be consistent with previous reports that show that HIF1- $\alpha$ haploinsufficiency, contrary to what happens in heart, does not rescue brain defects in Cited2 KO embryos (Xu et al., 2007). 
Cited2-mediated death occurs via PPAR $\gamma$ activation

Interestingly, Cited 2 is known to be able to act as a ligand-independent coactivator of PPAR $\gamma$ (Tien et al., 2004). The role of PPAR $\gamma$ in neuronal death induced by DNA damage is unclear. Accordingly, we first determined whether PPAR $\gamma$ might play a role in our system of neuronal death. As shown in Figure 6A, GW9662, a specific, potent, and irreversible antagonist of PPAR $\gamma$ (Leesnitzer et al., 2002), significantly delayed death at 10-30 $\mu \mathrm{M}$ concentrations. In addition, caspase 3 activation normally observed after DNA damage (Stefanis et al., 1999; Morris et al., 2001) was significantly decreased after treatment with the GW9662 inhibitor (Fig. 6B).

The above experiments indicate that PPAR $\gamma$ blockers delay death induced by campto treatment. If our model that Cited 2 signals death through PPAR $\gamma$ were true, we would anticipate that death induced by direct Cited 2 expression would also be blocked by GW9662. As shown in Figure $6 C$, this antagonist significantly inhibited the death induced by both Cited2 expression alone as well as with campto/ Cited 2 cotreatment. Finally, consistent with the model that the Cited2-mediated signal acts upstream of the mitochondria, GW9662 treatment also blocked cyt $c$ release (Fig. 6D).

We also explored the converse effects of PPAR $\gamma$ activation by ciglitazone, a PPAR $\gamma$ agonist (Willson et al., 1996), on death of cortical neurons. As shown in Figure $7 A$, ciglitazone induces death of cortical neurons even in the absence of DNA damage, supporting the notion that PPAR $\gamma$ activation can act as a death effector. Ciglitazone treatment also did not appear to further increase campto-induced death (Fig. $7 B$ ). Because ciglitazone may have other targets other than PPAR $\gamma$, we examined whether the death-promoting effect of ciglitazone was dependent on PPAR $\gamma$. Expression of a double mutant (L468A/E471A) form of PPAR $\gamma$ has been shown to be a potent dominant-negative inhibitor of wild-type PPAR $\gamma$ activity (Gurnell et al., 2000). Accordingly, we first show that expression of DNPPAR $\gamma$ blocks death of cortical neurons exposed to DNA damage (Fig. 7C). This supports the protection observed with pharmacological inhibition of PPAR $\gamma$. Second, DNPPAR $\gamma$ expression also blocked death caused by ciglitazone supporting the specificity of the agonist. Interestingly, we show that death induced by ciglitazone is actually dependent on Cited2 (Fig. 7D). This would be consistent with the notion that Cited 2 is required coactivator of PPAR $\gamma$ to induce death.
A

Flavo.
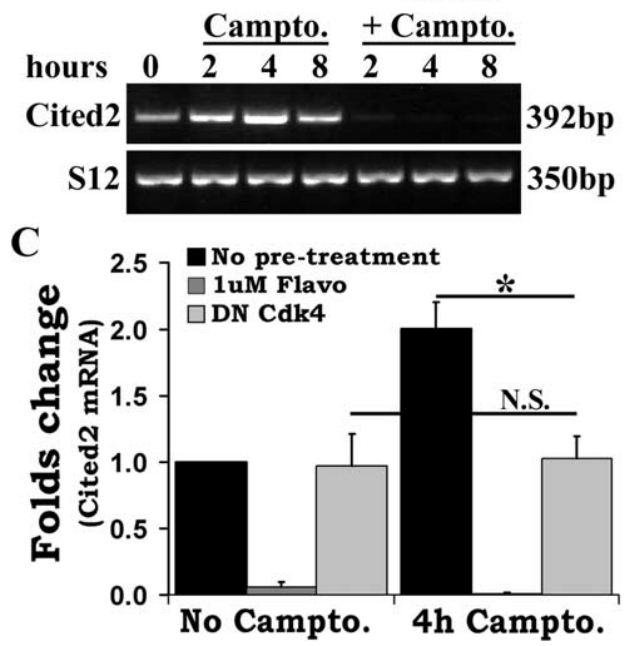

B

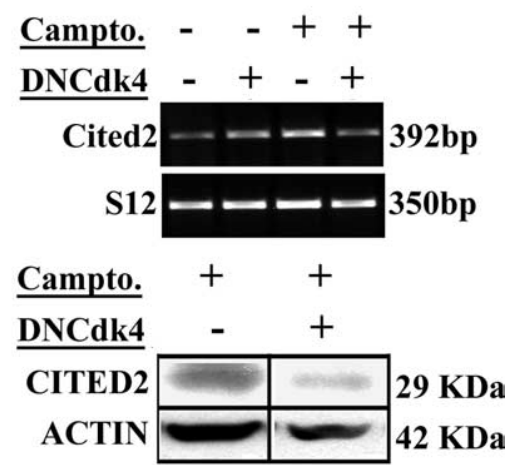

Figure 4. Cited2 upregulation is blocked by Cdk4 inhibition. $\boldsymbol{A}$, Cortical neurons were treated with campto and/or $1 \mu \mathrm{m}$ flavopiridol. Total RNA was extracted at indicated times and submitted to RT-PCR. Image from one representative experiment is shown. $\boldsymbol{B}$, Downregulation of endogenous Cdk4 activity inhibits Cited 2 upregulation. Cortical neurons were infected with $150 \mathrm{M} 0 \mathrm{I}$ of DNCdk4 or GFP control expressing AAV as indicated in Materials and Methods. After 6-7 DIV, neurons were treated with $10 \mu \mathrm{M}$ campto for indicated times. Total RNA or protein was extracted and submitted to RT-PCR (top) or Western blot (bottom). Images show results from one representative experiment. C, Normalized RT-PCR densitometry data from flavopiridol and DNCdk4 experiments are presented as fold increase relative to nontreated sample. Each bar represents the mean \pm SEM from at least three independent experiments. ${ }^{*} p<0.05$; N.S., no significant difference.

A
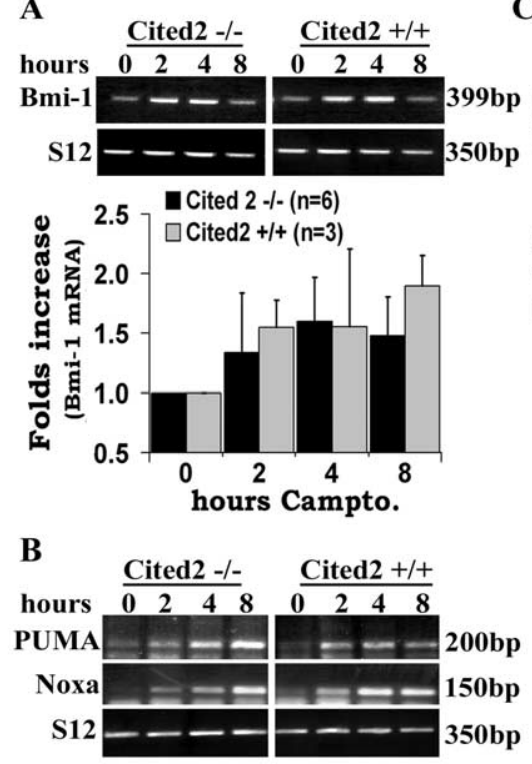

C

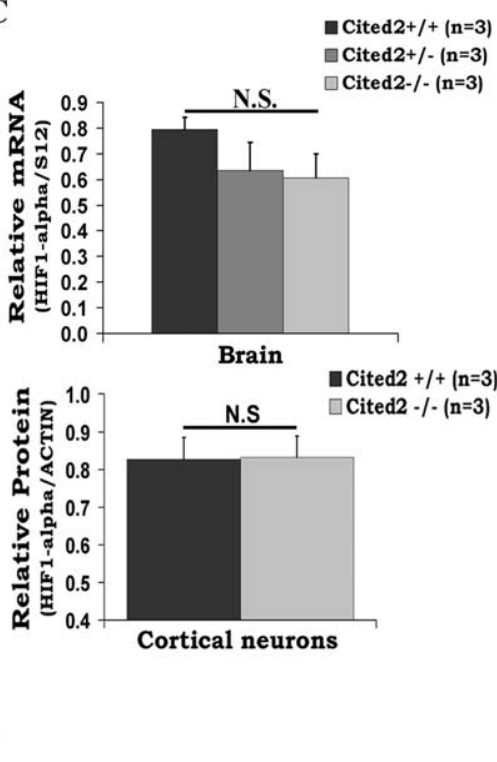

Figure 5. Cited2 deficiency does not affect Bmi-1 upregulation, p53 activity, or basal HIF1- $\alpha$ levels. $A, B$, Embryonic cortical neurons derived from heterozygous Cited 2 crosses were independently cultured and treated with $10 \mu \mathrm{m}$ campto as indicated. Total RNA was extracted and subjected to RT-PCR for Bmi-1, PUMA, Noxa, and S12. A, Top, RT-PCR results from representative embryos. Signals were analyzed by densitometry and Bmi-1 signal was normalized using S12. Bottom, Data are presented as fold increase relative to nontreated sample for each embryo. Each bar represents the mean \pm SEM for $n$ embryos. $\boldsymbol{B}, \mathrm{RT}-\mathrm{PCR}$ results for Puma and Noxa transcripts from representative embryos. $C$, Quantitation of HIF1- $\alpha$ basal levels. The top panel shows mRNA levels in whole brains from littermates embryos from heterozygous Cited 2 crosses. Data are presented as normalized values relative to S12 signal for each embryo. The bottom panel shows protein results from independently cultured cortical neurons from littermates embryos from heterozygous Cited2 crosses. Data are presented as normalized values relative to actin signal for each embryo. The bars represent the mean \pm SEM from $n$ embryos of specified genotype. N.S., No significant difference.

To further support the importance of $\operatorname{PPAR} \gamma$, we next determined whether its activity is induced after DNA damage. To do this, we used a reporter system, which consisted of luciferase expressed under the regulation of a PPAR $\gamma$-responsive element 
A
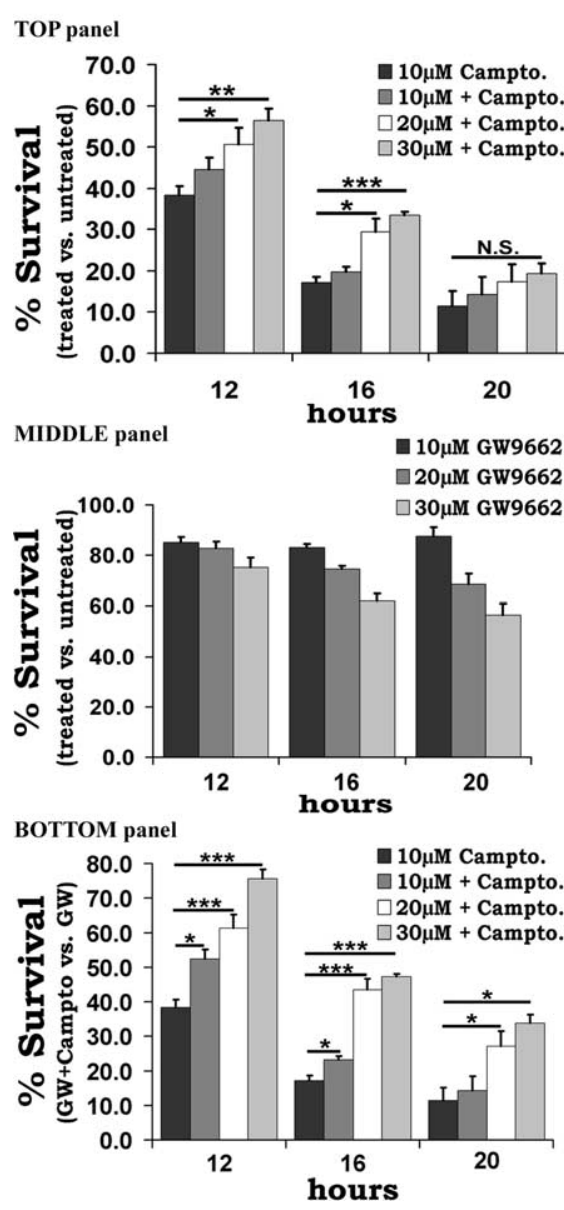

\section{D}
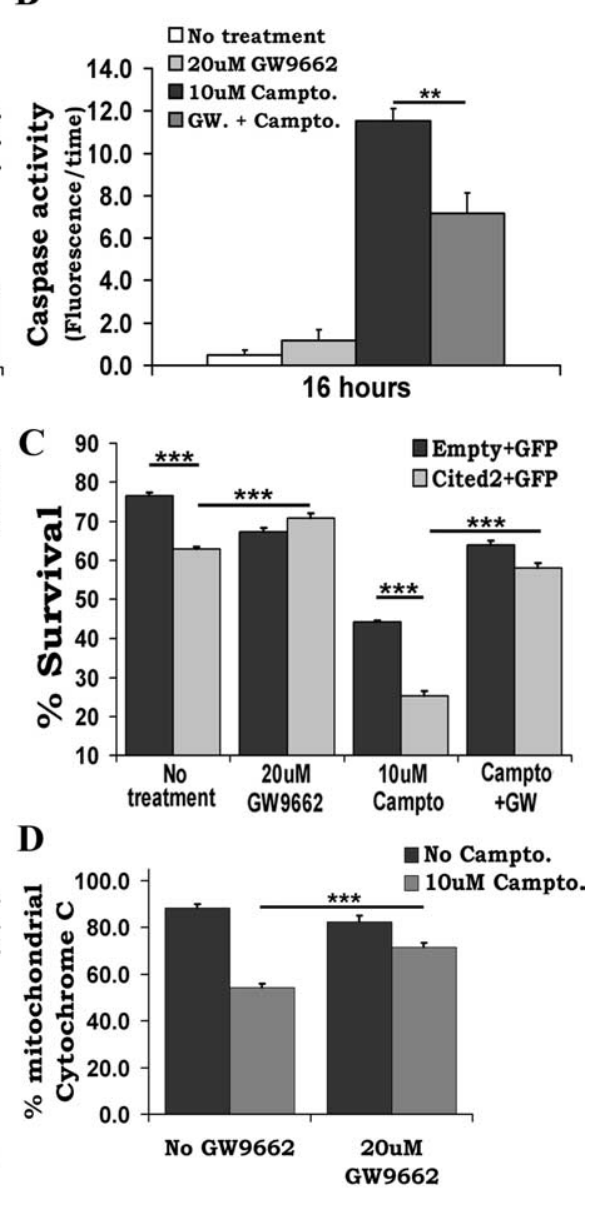

Figure 6. Effects of PPAR $\gamma$ inhibition with GW9662. A, GW9662 protects cortical neurons from DNA damage. After 4 DIV, cortical neurons were treated with $10 \mu \mathrm{m}$ campto alone or together with GW9662 at various concentrations ( $10-30 \mu \mathrm{m})$. Cells were lysed and intact nuclei were counted as described in Materials and Methods. The top panel quantifies neurons treated with campto and GW9662 when compared with untreated controls. Percentage survival was calculated as the number of remaining live nuclei in treated wells compared with completely untreated cultures. The middle panel quantifies neurons treated only with GW9662. Percentage survival was calculated as the number of remaining live nuclei in treated wells compared with completely untreated controls. The bottom panel shows values when neurons treated with campto and GW9662 are compared with those form neurons treated only with GW9662. The bars represent the mean \pm SEM from at least three independent experiments. ${ }^{*} p<$ $0.05 ;{ }^{* *} p<0.01 ;{ }^{* * *} p<0.001$; N.S., no significant difference. $B$, GW9662 inhibits caspase activation induced by DNA damage. Cortical neurons were treated with campto alone or together with $20 \mu \mathrm{M} \mathrm{GW} 9662$ for $16 \mathrm{~h}$. Protein was extracted as described in Materials and Methods, and caspase activity was determined in triplicate as the slope of linear regression (fluorescence vs time plot) for each replica. Each bar represents the mean \pm SEM from four independent experiments. ${ }^{* *} p<0.01$. C, Cited2-induced death of cortical neurons is inhibited by GW9662. Seventy-two to $96 \mathrm{~h}$ after plating, cortical neurons were transiently cotransfected with empty pcDNA3 or pcDNA3-Cited 2 and pEGPF using Lipofectamine. Twenty-four hours after, $10 \mu m$ campto and/or 20 $\mu \mathrm{M}$ GW9662 was added and incubated for $21 \mathrm{~h}$ followed by fixation and Hoechst 33258 staining. At least $100 \mathrm{GFP}$-positive nuclei per treatment were assessed. Percentage survival was calculated as percentage of live over total GFP-expressing neurons. Data represent the mean \pm SEM from three independent experiments. ${ }^{* *} p<0.001$. D, GW9662 blocks cytochrome $c$ release from the mitochondria after DNA damage. Cortical neurons were cultured and treated with campto and/or $20 \mu \mathrm{m}$ GW9662 for $12 \mathrm{~h}$, followed by fixation and cyt $c /$ Hoechst 33258 staining. Quantitation is presented as percentage of neurons positive for punctate cyt c. Data represent the mean \pm SEM from three independent experiments. ${ }^{* * *} p<0.001$.

(PPRE-luciferase). As shown in Figure $8 A$, PPAR $\gamma$ activity is upregulated after DNA damage, with a peak $3 \mathrm{~h}$ after initiation of campto exposure (Fig. $8 \mathrm{D}$ ). This induction was inhibited by the Cdk inhibitor flavopiridol, consistent with the model that Cdks are upstream regulators of PPAR $\gamma$ (Fig. 8A). The induction of PPAR $\gamma$ activity could not be accounted for by upregulation of PPAR $\gamma$ levels. In fact, PPAR $\gamma$ mRNA levels appear to decrease after DNA damage (Fig. 8 B). PPAR $\gamma$ protein was also not significantly elevated after campto exposure (Fig. $8 C$ ). We also examined another PPAR family member with the potential to be acti- vated by Cited2, PPAR $\alpha$. Its protein level was not significantly altered after DNA damage (our unpublished data).

To test whether PPAR $\gamma$ activation after DNA damage is Cited2 dependent, we measured PPAR $\gamma$ reporter activity after DNA damage in cultured neurons derived from Cited2-deficient cultures or WT littermate controls (Fig. 8D). We found that Cited 2 deficiency significantly blocked the upregulation of PPAR $\gamma$ activation. Importantly, the basal level of PPAR $\gamma$ activity was not different between Cited2-deficient and WT neurons (Fig. 8E).

If Cited 2 was critical for PPAR $\gamma$ activation, we would predict that exogenous expression of Cited 2 in neurons would induce PPAR $\gamma$ activity, similar to DNA damage. Indeed, we found this to be the case. As shown in Figure $8 F$, Cited 2 expression alone caused an induction of PPAR $\gamma$ reporter activity similar to that of campto treatment (Fig. $8 \mathrm{~A}$ ).

Finally, if Cited 2 acts as a coactivator of PPAR $\gamma$ (Tien et al., 2004), we would anticipate that they should interact. We examined this possibility in neurons untreated and treated with campto by IP/Western blot analyses. In this experiment, Cited 2 was immunoprecipitated from cell extracts untreated or treated with campto followed by Western blot analyses for $\operatorname{PPAR} \gamma$. As shown in Figure 8G, we detected very little basal interaction between Cited 2 and PPAR $\gamma$. However, significant interaction was observed after treatment with campto. The above data suggest that Cited2 is required for DNA damageinduced PPAR $\gamma$ activation and subsequent cell death.

Together, these results present a model by which Cdk4-mediated induction of Cited2 leads to activation of $\operatorname{PPAR} \gamma$, caspase activation, and consequent neuronal death.

\section{Discussion}

Integrity and fidelity of DNA is essential for the proper function and survival of neurons. However, our understanding of the complex signals that govern neuronal death after DNA damage is incomplete. We previously showed that cell cycle Cdks as well as p53 regulate the mitochondrial pathway of death (Morris et al., 2001). We presently provide additional critical insight into signals that participate in DNA damage-induced death. Our results indicate that Cited2 is upregulated in a manner dependent on the cell cycle Cdk4 pathway, upstream of the mitochondrial pathway. Importantly, we also provide data that indicate a proapoptotic role for Cited 2 and that Cited 2 promotes death through direct activation of PPAR $\gamma$. Together, our results define a unique Cdk4-Cited2-PPAR $\gamma$-mediated pathway that regulates DNA damage-induced neuronal death. 


\section{Prodeath role of Cited 2}

The role of Cited 2 in neuronal death had never before been examined. Nevertheless, a number of correlational observations have suggested that Cited 2 might be somehow linked to neuronal survival (Sun et al., 2007). For example, $57 \%$ of Cited $2 \mathrm{KO}$ embryos exhibit enhanced apoptosis of midbrain cells (Bamforth et al., 2001). Cited 2 upregulation could be detected by in situ hybridization in the hippocampus after global ischemia, but predominately, in areas which are spared (dentate gyrus) rather than injured (CA1) (Sun et al., 2006). These observations suggested that Cited 2 might be functioning as a prosurvival gene to inhibit neuronal death. However, alternative explanations for these observations could be provided. As one example, death of midbrain cells in Cited2 $\mathrm{KO}$ embryos could be a non-cellautonomous event caused by other defects.

Presently, we confirm an increase in Cited2 levels in cultured neurons after DNA damage. More importantly, we present direct evidence that define, for the first time, the role of Cited 2 in neuronal death/survival. Unlike previous suggestions, we show that Cited2 plays a proapoptotic role after DNA damage. Our evidence is as follows: (1) Cited 2 message and protein are increased at early stages after insult, (2) exogenous expression of Cited 2 promotes neuronal death, and (3) Cited2 deficiency significantly delays death after DNA damage. Whether Cited2 functions similarly in other neuronal injury paradigms is unknown. However, we observed similar increases of Cited 2 message in the CA1 region of the hippocampus of rats after global ischemia (our unpublished data). This suggests the possibility that Cited 2 may also play a role in neuronal death under other contexts. It is important to emphasize that Cited 2 deficiency is only partially protective. This is consistent with the notion that multiple signals act in concert to regulate neuronal death after DNA damage (Morris et al., 2001; Ghahremani et al., 2002; Keramaris et al., 2003; Sedarous et al., 2003; Aleyasin et al., 2004).

\section{Mechanism for Cited 2 upregulation}

Our present studies also begin to define the pathway by which Cited 2 is induced. Our results indicate that the early increase in Cited 2 message is not attributable to several critical signals we previously established to be important in this paradigm of death. These include (1) the mitochondrial pathway of death (Putcha et al., 1999; Keramaris et al., 2000; Cregan et al., 2002), (2) p53 (Morris et al., 2001; Vaughn and Deshmukh, 2007), and (3) JNKs (Ghahremani et al., 2002; Besirli and Johnson, 2003). Instead, our studies reveal that Cdk4 activity is critical for early Cited 2 induction. We previously showed that cyclin D1-associated Cdks $(\mathrm{Cdk} 4 / 6)$ are aberrantly activated in neurons after DNA damage (Park et al., 1998) and various different in vitro neuronal death paradigms (Park et al., 1996, 1997b; Giovanni et al., 1999; Padmanabhan et al., 1999; Rideout et al., 2003). This evidence also extends to in vivo injury and neurodegenerative contexts including after stroke/ischemia (Osuga et al., 2000), Alzheimer's disease (McShea et al., 1997; Biswas et al., 2007), and amyotrophic lateral sclerosis (Nguyen et al., 2003). We and others have shown that Cdk4/6 activity is essential to signal death in many paradigms of neuronal apoptosis, including after DNA damage in vitro (Park et al., 1998; Morris et al., 2001; Zhang et al., 2006) and stroke in vivo (Rashidian et al., 2005). Moreover, classic downstream targets of $\mathrm{Cdk} 4, \mathrm{Rb}$, and E2F, have also been shown to be critical for neuronal death. We and others showed that $\mathrm{Cdk} 4$ regulates the activity of Rb by phosphorylation and its subsequent inactivation, and so releasing E2F transcription factors from inactivity (Giovanni et al., 2000; Park et al., 2000; Gendron et al., 2001). E2F activation in turn induces the upregulation of proapoptotic genes, such as B- and C-myb (Liu et al., 2004; Biswas et al., 2005; Greene et al., 2007).

What is the link between cell cycle activation and Cited2? Cited 2 has been linked to cell transformation (Sun et al., 1998; Chou and Yang, 2006; Haase et al., 2007). Additionally, Cited2 overexpression enhances fibroblast proliferation and Cited 2 deficiency prematurely stops proliferation. It was proposed that Cited 2 stimulates proliferation by induction of Bmi-1 that in turn represses the INK4/ARF locus of cell cycle inhibitors (Kranc et al., 2003). In the context of our present work, this suggested the intriguing connection that cell cycle may be activated by Cited 2 expression through induction of Bmi-1. However, our results show that, although Bmi-1 is induced after DNA damage, it is not 


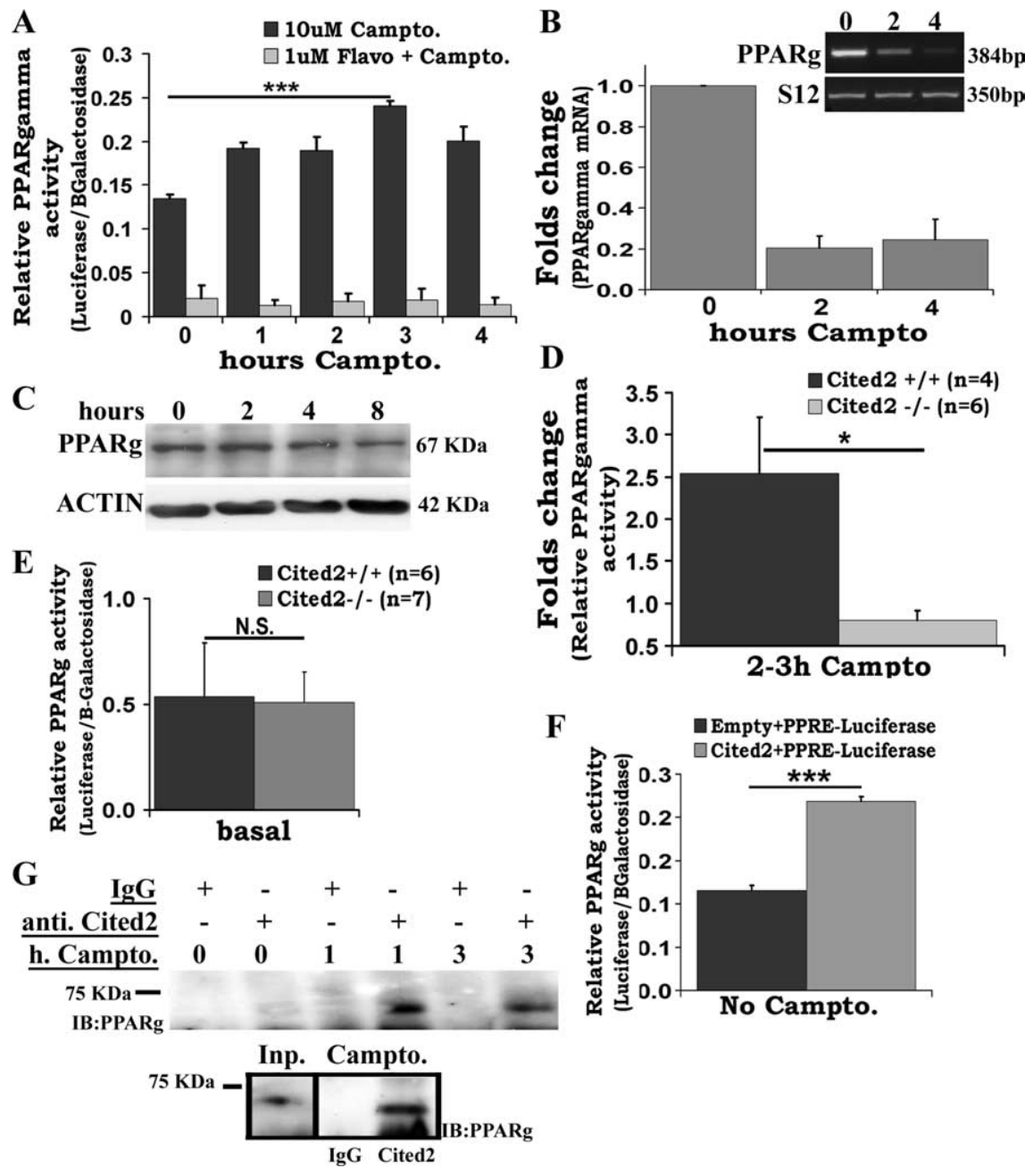

Figure 8. PPAR $\gamma$ activity, but not levels, is upregulated after DNA damage in a Cdk-Cited2-dependent manner. A, PPAR $\gamma$ activity increases after DNA damage and is blocked by the Cdk inhibitor flavopiridol. Seventy-two hours after plating, cortical neurons were transiently cotransfected with PPRE-luciferase- and CMV- $\beta$-galactosidase-expressing plasmids using Lipofectamine as described in Materials and Methods. Twenty-four hours after, cells were treated with $10 \mu \mathrm{m}$ campto and/or $1 \mu \mathrm{m}$ flavopiridol for specified times. Data represent values of luciferase/ $\beta$-galactosidase activity. Bars represent the mean \pm SEM from four independent experiments. ${ }^{* * *} p<0.001$. B, PPAR $\gamma$ message decreases after DNA damage. Cortical neurons were treated with campto at indicated times. Total RNA was extracted and RT-PCR result from one representative experiment is shown in inset. Normalized densitometry data are presented as fold change relative to nontreated sample. Each bar represents the mean \pm SEM from three independent experiments. $\boldsymbol{C}$, Total protein was extracted from campto-treated cortical neurons and analyzed by Western blot as described. Results from one representative experiment are shown. $\boldsymbol{D}$, Cited 2 deficiency blocks PPAR $\gamma$ activity upregulation by campto. Seventy-two hours after plating, cortical neurons from littermate embryos from heterozygous Cited2 crosses independently cultured were transfected and treated with $10 \mu \mathrm{m}$ campto to assess PPAR $\gamma$ activity as described above. Values represent fold change of normalized luciferase activity (luciferase/ $\beta$-galactosidase) of correspondent sample relative to transfected nontreated sample. Each bar represents the mean \pm SEM from $n$ embryos. ${ }^{*} p<0.05$. E, Basal PPAR $\gamma$ activity does not differ between Cited $2 \mathrm{KO}$ and WT neurons. PPAR $\gamma$ activity was measured as described in $\boldsymbol{D}$ and presented as normalized luciferase activity (luciferase/ $\beta$-galactosidase). The bars represent the mean \pm SEM from $n$ independently cultured embryos. N.S., No significant difference. $\boldsymbol{F}$, Cited 2 overexpression induces PPAR $\gamma$ activity. Seventy-two to 96 h after plating, cortical neurons were transiently cotransfected with empty pcDNA3 or pcDNA3-Cited2-, PPRE-luciferase-, and CMV- $\beta$-galactosidase-expressing plasmids using Lipofectamine. Twenty-four hours after, luciferase activity was evaluated as described in Materials and Methods. Data are presented as normalized luciferase activity (luciferase/ $\beta$-galactosidase). Each bar represents the mean \pm SEM from three independent experiments. ${ }^{* * *} p<0.001$. G, Cited2 and PPAR $\gamma$ interact after DNA damage. Cortical neurons were treated with campto at indicated times and total protein was extracted as indicated in Materials and Methods. Control lgG or anti-Cited 2 antibodies were incubated with total cell lysates ( $\sim 2 \times 10^{7}$ neurons). Antibodies were isolated by IP beads and resolved by SDS-PAGE followed by anti-PPAR $\gamma$ Western blot. Results from two independent experiments are shown. Inp., Input, TCA precipitate from total cell lysate ( $\sim 10^{7}$ untreated neurons).

regulated by Cited2. This indicates that it is unlikely that Cited2 acts upstream of Cdk4 activation.

In contrast, our present data point out that inhibition of Cdk4 blocks Cited 2 induction suggesting that Cited2 is a downstream target of Cdk4. Whether $\mathrm{Cdk} 4$ regulation of Cited2 is through the classic $\mathrm{Rb} / \mathrm{E} 2 \mathrm{~F}$ pathway described above is unknown. A search of mouse Cited 2 promoter using TRANSFAC software (version4.0database7-publicI) and Genomatix/ Gene2Promoter analysis both revealed no clear consensus binding sites for E2F, C-myb, or B-myb. However, the same search exposed an AP-1 putative interacting site $(-1110$ to -1101$)$. In this regard, c-Jun has been shown to interact with the Cited 2 promoter in human proliferating cells (Hayakawa et al., 2004). Intriguingly, our previous work in our model of DNA damage-induced neuronal death indicated that c-Jun activation was dependent on Cdk4 activation (Ghahremani et al., 2002) as well as the classic upstream JNK family members. Our present results indicate that JNKs only partially regulate Cited 2 induction and at late times, whereas $\mathrm{Cdk} 4$ more robustly regulated Cited 2 levels. This is identical with that we previously reported for regulation of c-Jun. This suggests the possibility of Cited2 being a c-Jun target after DNA damage. However, more careful analyses will have to be performed to clarify this issue.

Mechanism for Cited2-mediated death Our present results indicate that one important mechanism by which Cited 2 promotes death is through regulation of $\operatorname{PPAR} \gamma$. PPAR $\gamma$ is a complex signal with both proapoptotic (Rohn et al., 2001) as well as protective functions (Arnold and Konig, 2006; Collino et al., 2006). The role of PPAR $\gamma$ likely depends on the context of the cell or model system. For example, $\operatorname{PPAR} \gamma$ is known to regulate neuroinflammation by inhibiting microglial activation (Bernardo and Minghetti, 2006). In this context, PPAR $\gamma$ activation strategies would be expected to promote survival under contexts in which inflammation is a critical component of injury. However, PPAR $\gamma$ activation is also able to promote death of multiple cell types including neurons (Zhang et al., 2005).

Our findings indicate that PPAR $\gamma$ participates in the death of neurons after DNA damage. This is supported by the following: (1) PPAR $\gamma$ activity is increased after DNA damage, (2) inhibition of PPAR $\gamma$ activation through multiple means promotes survival, and (3) PPAR $\gamma$ agonist can induce death. Importantly, we also show that the upregulation of PPAR $\gamma$ activity is dependent on Cited 2 and that PPAR $\gamma$ is a critical mediator of Cited2-induced death. This notion is substantiated by the observations that (1) Cited 2 expression is sufficient to activate PPAR $\gamma$ and Cited 2 deficiency inhibits DNA damage-induced PPAR $\gamma$ ac- 


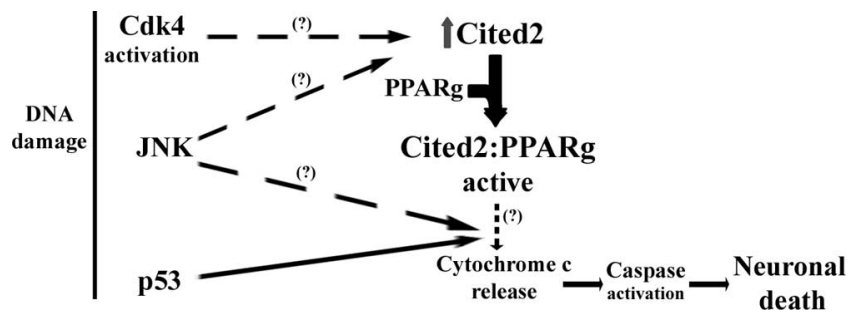

Figure 9. Proposed model of the Cdk4-Cited2-PPAR $\gamma$ pathway of neuronal death. This model is based on previous and present results. Links that have been inferred but need to be tested for directness are identified with question marks. In this scheme, Cdk4 activation by DNA damage induces the upregulation of Cited2 levels. Cited 2 in turn recruits PPAR $\gamma$ and by this interaction causes PPAR $\gamma$ activation. The Cited2:PPAR $\gamma$ complex leads to cytochrome c release and subsequent caspase activation, followed by neuronal death.

tivation, (2) PPAR $\gamma$ inhibition blocks Cited2-mediated death, and (3) Cited 2 deficiency inhibits death induced by PPAR $\gamma$ agonist. The latter two points also suggest that both Cited 2 and $\operatorname{PPAR} \gamma$ require each other to induce death. It must be noted that we do not know whether Cited2-mediated activation of PPAR $\gamma$ is direct. However, our results show that PPAR $\gamma$ activation could be accounted for by increase in Cited 2 levels, because Cited 2 upregulation at $2 \mathrm{~h}$ after campto is already significant. Moreover, we see an early increase in an interaction between PPAR $\gamma$ and Cited 2 as revealed by IP/Western blot, suggesting a more direct mechanism of action.

Our work defines, for the first time, the circumstances of Cited2 as a proapoptotic signal in neurons (Fig. 9). It is not known whether Cited 2 may also play similar roles in adult contexts of neuronal injury such as with stroke. However, it is important to point out that similar players such as cell cycle signals are also critical in adult models of injury (Rashidian et al., 2005). Whether Cited2, then, mediates the prodeath function of cell cycle signals in ischemic death will be an intriguing area of future study.

\section{References}

Aleyasin H, Cregan SP, Iyirhiaro G, O'Hare MJ, Callaghan SM, Slack RS, Park DS (2004) Nuclear factor- $\kappa$ B modulates the $\mathrm{p} 53$ response in neurons exposed to DNA damage. J Neurosci 24:2963-2973.

Aminova LR, Chavez JC, Lee J, Ryu H, Kung A, Lamanna JC, Ratan RR (2005) Prosurvival and prodeath effects of hypoxia-inducible factorlalpha stabilization in a murine hippocampal cell line. J Biol Chem 280:3996-4003.

Arnold R, Konig W (2006) Peroxisome-proliferator-activated receptorgamma agonists inhibit the release of proinflammatory cytokines from RSV-infected epithelial cells. Virology 346:427-439.

Bamforth SD, Braganca J, Eloranta JJ, Murdoch JN, Marques FI, Kranc KR, Farza H, Henderson DJ, Hurst HC, Bhattacharya S (2001) Cardiac malformations, adrenal agenesis, neural crest defects and exencephaly in mice lacking Cited2, a new Tfap2 co-activator. Nat Genet 29:469-474.

Bernardo A, Minghetti L (2006) PPAR-gamma agonists as regulators of microglial activation and brain inflammation. Curr Pharm Des 12:93-109.

Besirli CG, Johnson Jr EM (2003) JNK-independent activation of c-Jun during neuronal apoptosis induced by multiple DNA-damaging agents. J Biol Chem 278:22357-22366.

Bhattacharya S, Ratcliffe PJ (2003) ExCITED about HIF. Nat Struct Biol 10:501-503.

Bhattacharya S, Michels CL, Leung MK, Arany ZP, Kung AL, Livingston DM (1999) Functional role of $\mathrm{p} 35 \mathrm{srj}$, a novel p300/CBP binding protein, during transactivation by HIF-1. Genes Dev 13:64-75.

Biswas SC, Liu DX, Greene LA (2005) Bim is a direct target of a neuronal E2F-dependent apoptotic pathway. J Neurosci 25:8349-8358.

Biswas SC, Shi Y, Vonsattel JP, Leung CL, Troy CM, Greene LA (2007) Bim is elevated in Alzheimer's disease neurons and is required for $\beta$-amyloidinduced neuronal apoptosis. J Neurosci 27:893-900.

Chou YT, Yang YC (2006) Posttranscriptional control of Cited2 by TGF- beta: regulation via Smads and cited2 coding region. J Biol Chem 281:18451-18462.

Collino M, Aragno M, Mastrocola R, Gallicchio M, Rosa AC, Dianzani C, Danni O, Thiemermann C, Fantozzi R (2006) Modulation of the oxidative stress and inflammatory response by PPAR-gamma agonists in the hippocampus of rats exposed to cerebral ischemia/reperfusion. Eur J Pharmacol 530:70-80.

Cregan SP, MacLaurin JG, Craig CG, Robertson GS, Nicholson DW, Park DS, Slack RS (1999) Bax-dependent caspase-3 activation is a key determinant in p53-induced apoptosis in neurons. J Neurosci 19:7860-7869.

Cregan SP, Fortin A, MacLaurin JG, Callaghan SM, Cecconi F, Yu SW, Dawson TM, Dawson VL, Park DS, Kroemer G, Slack RS (2002) Apoptosisinducing factor is involved in the regulation of caspase-independent neuronal cell death. J Cell Biol 158:507-517.

Cregan SP, Arbour NA, Maclaurin JG, Callaghan SM, Fortin A, Cheung EC, Guberman DS, Park DS, Slack RS (2004) p53 activation domain 1 is essential for PUMA upregulation and p53-mediated neuronal cell death. J Neurosci 24:10003-10012.

Fortin A, Cregan SP, MacLaurin JG, Kushwaha N, Hickman ES, Thompson CS, Hakim A, Albert PR, Cecconi F, Helin K, Park DS, Slack RS (2001) APAF1 is a key transcriptional target for p 53 in the regulation of neuronal cell death. J Cell Biol 155:207-216.

Freedman SJ, Sun ZY, Kung AL, France DS, Wagner G, Eck MJ (2003) Structural basis for negative regulation of hypoxia-inducible factor1alpha by CITED2. Nat Struct Biol 10:504-512.

Gendron TF, Mealing GA, Paris J, Lou A, Edwards A, Hou ST, MacManus JP, Hakim AM, Morley P (2001) Attenuation of neurotoxicity in cortical cultures and hippocampal slices from E2F1 knockout mice. J Neurochem 78:316-324.

Ghahremani MH, Keramaris E, Shree T, Xia Z, Davis RJ, Flavell R, Slack RS, Park DS (2002) Interaction of the c-Jun/JNK pathway and cyclindependent kinases in death of embryonic cortical neurons evoked by DNA damage. J Biol Chem 277:35586-35596.

Giovanni A, Wirtz-Brugger F, Keramaris E, Slack R, Park DS (1999) Involvement of cell cycle elements, cyclin-dependent kinases, $\mathrm{pRb}$, and $\mathrm{E} 2 \mathrm{~F} \times \mathrm{DP}$, in $\beta$-amyloid-induced neuronal death. J Biol Chem 274:19011-19016.

Giovanni A, Keramaris E, Morris EJ, Hou ST, O’Hare M, Dyson N, Robertson GS, Slack RS, Park DS (2000) E2F1 mediates death of $\beta$-amyloid-treated cortical neurons in a manner independent of p53 and dependent on Bax and caspase 3. J Biol Chem 275:11553-11560.

Greene LA, Liu DX, Troy CM, Biswas SC (2007) Cell cycle molecules define a pathway required for neuron death in development and disease. Biochim Biophys Acta 1772:392-401.

Gurnell M, Wentworth JM, Agostini M, Adams M, Collingwood TN, Provenzano C, Browne PO, Rajanayagam O, Burris TP, Schwabe JW, Lazar MA, Chatterjee VK (2000) A dominant-negative peroxisome proliferator-activated receptor gamma (PPARgamma) mutant is a constitutive repressor and inhibits PPARgamma-mediated adipogenesis. J Biol Chem 275:5754-5759.

Haase M, Schott M, Bornstein SR, Malendowicz LK, Scherbaum WA, Willenberg HS (2007) CITED2 is expressed in human adrenocortical cells and regulated by basic fibroblast growth factor. J Endocrinol 192:459-465.

Hayakawa J, Mittal S, Wang Y, Korkmaz KS, Adamson E, English C, Omichi M, McClellan M, Mercola D (2004) Identification of promoters bound by c-jun/ATF2 during rapid large-scale gene activation following genotoxic stress. Mol Cell 16:521-535.

Keramaris E, Stefanis L, MacLaurin J, Harada N, Takaku K, Ishikawa T, Taketo MM, Robertson GS, Nicholson DW, Slack RS, Park DS (2000) Involvement of caspase 3 in apoptotic death of cortical neurons evoked by DNA damage. Mol Cell Neurosci 15:368-379.

Keramaris E, Hirao A, Slack RS, Mak TW, Park DS (2003) Ataxia telangiectasia-mutated protein can regulate $\mathrm{p} 53$ and neuronal death independent of Chk2 in response to DNA damage. J Biol Chem 278:37782-37789.

Kranc KR, Bamforth SD, Braganca J, Norbury C, van Lohuizen M, Bhattacharya S (2003) Transcriptional coactivator Cited2 induces Bmil and Mel18 and controls fibroblast proliferation via Ink4a/ARF. Mol Cell Biol 23:7658-7666.

Leesnitzer LM, Parks DJ, Bledsoe RK, Cobb JE, Collins JL, Consler TG, Davis RG, Hull-Ryde EA, Lenhard JM, Patel L, Plunket KD, Shenk JL, Stimmel 
JB, Therapontos C, Willson TM, Blanchard SG (2002) Functional consequences of cysteine modification in the ligand binding sites of peroxisome proliferator activated receptors by GW9662. Biochemistry 41:6640-6650.

Liu DX, Biswas SC, Greene LA (2004) B-myb and C-myb play required roles in neuronal apoptosis evoked by nerve growth factor deprivation and DNA damage. J Neurosci 24:8720-8725.

McShea A, Harris PL, Webster KR, Wahl AF, Smith MA (1997) Abnormal expression of the cell cycle regulators P16 and CDK4 in Alzheimer's disease. Am J Pathol 150:1933-1939.

Morris EJ, Keramaris E, Rideout HJ, Slack RS, Dyson NJ, Stefanis L, Park DS (2001) Cyclin-dependent kinases and p53 pathways are activated independently and mediate Bax activation in neurons after DNA damage. J Neurosci 21:5017-5026.

Nguyen MD, Boudreau M, Kriz J, Couillard-Despres S, Kaplan DR, Julien JP (2003) Cell cycle regulators in the neuronal death pathway of amyotrophic lateral sclerosis caused by mutant superoxide dismutase 1. J Neurosci 23:2131-2140.

O'Hare MJ, Hou ST, Morris EJ, Cregan SP, Xu Q, Slack RS, Park DS (2000) Induction and modulation of cerebellar granule neuron death by E2F-1. J Biol Chem 275:25358-25364.

Osuga H, Osuga S, Wang F, Fetni R, Hogan MJ, Slack RS, Hakim AM, Ikeda JE, Park DS (2000) Cyclin-dependent kinases as a therapeutic target for stroke. Proc Natl Acad Sci USA 97:10254-10259.

Padmanabhan J, Park DS, Greene LA, Shelanski ML (1999) Role of cell cycle regulatory proteins in cerebellar granule neuron apoptosis. J Neurosci 19:8747-8756.

Park DS, Stefanis L, Yan CY, Farinelli SE, Greene LA (1996) Ordering the cell death pathway. Differential effects of BCL2, an interleukin-1converting enzyme family protease inhibitor, and other survival agents on JNK activation in serum/nerve growth factor-deprived PC12 cells. J Biol Chem 271:21898-21905.

Park DS, Morris EJ, Greene LA, Geller HM (1997a) G G/S cell cycle blockers and inhibitors of cyclin-dependent kinases suppress camptothecininduced neuronal apoptosis. J Neurosci 17:1256-1270.

Park DS, Levine B, Ferrari G, Greene LA (1997b) Cyclin dependent kinase inhibitors and dominant negative cyclin dependent kinase 4 and 6 promote survival of NGF-deprived sympathetic neurons. J Neurosci 17:8975-8983.

Park DS, Morris EJ, Padmanabhan J, Shelanski ML, Geller HM, Greene LA (1998) Cyclin-dependent kinases participate in death of neurons evoked by DNA-damaging agents. J Cell Biol 143:457-467.

Park DS, Morris EJ, Bremner R, Keramaris E, Padmanabhan J, Rosenbaum M, Shelanski ML, Geller HM, Greene LA (2000) Involvement of retinoblastoma family members and E2F/DP complexes in the death of neurons evoked by DNA damage. J Neurosci 20:3104-3114.

Putcha GV, Deshmukh M, Johnson Jr EM (1999) BAX translocation is a critical event in neuronal apoptosis: regulation by neuroprotectants, BCL-2, and caspases. J Neurosci 19:7476-7485.

Rashidian J, Iyirhiaro G, Aleyasin H, Rios M, Vincent I, Callaghan S, Bland RJ, Slack RS, During MJ, Park DS (2005) Multiple cyclin-dependent kinases signals are critical mediators of ischemia/hypoxic neuronal death in vitro and in vivo. Proc Natl Acad Sci USA 102:14080-14085.

Rideout HJ, Wang Q, Park DS, Stefanis L (2003) Cyclin-dependent kinase activity is required for apoptotic death but not inclusion formation in cortical neurons after proteasomal inhibition. J Neurosci 23:1237-1245.

Rohn TT, Wong SM, Cotman CW, Cribbs DH (2001) 15-Deoxydelta12,14-prostaglandin J2, a specific ligand for peroxisome proliferatoractivated receptor-gamma, induces neuronal apoptosis. NeuroReport 12:839-843.

Sedarous M, Keramaris E, O'Hare M, Melloni E, Slack RS, Elce JS, Greer PA, Park DS (2003) Calpains mediate p53 activation and neuronal death evoked by DNA damage. J Biol Chem 278:26031-26038.

Stefanis L, Park DS, Friedman WJ, Greene LA (1999) Caspase-dependent and -independent death of camptothecin-treated embryonic cortical neurons. J Neurosci 19:6235-6247.

Sun HB, Zhu YX, Yin T, Sledge G, Yang YC (1998) MRG1, the product of a melanocyte-specific gene related gene, is a cytokine-inducible transcription factor with transformation activity. Proc Natl Acad Sci USA 95:13555-13560.

Sun W, Kim KH, Noh M, Hong S, Huh PW, Kim Y, Kim H (2006) Induction of CITED2 expression in the rat hippocampus following transient global ischemia. Brain Res 1072:15-18.

Sun W, Choi SH, Park SK, Kim SJ, Noh MR, Kim EH, Kim HJ, Kim H (2007) Identification and characterization of novel activity-dependent transcription factors in rat cortical neurons. J Neurochem 100:269-278.

Tien ES, Davis JW, Vanden Heuvel JP (2004) Identification of the CREBbinding protein/p300-interacting protein CITED2 as a peroxisome proliferator-activated receptor alpha coregulator. J Biol Chem 279:24053-24063.

Vaughn AE, Deshmukh M (2007) Essential postmitochondrial function of p53 uncovered in DNA damage-induced apoptosis in neurons. Cell Death Differ 14:973-981.

Willson TM, Cobb JE, Cowan DJ, Wiethe RW, Correa ID, Prakash SR, Beck KD, Moore LB, Kliewer SA, Lehmann JM (1996) The structure-activity relationship between peroxisome proliferator-activated receptor gamma agonism and the antihyperglycemic activity of thiazolidinediones. J Med Chem 39:665-668.

Xia Z, Dudek H, Miranti CK, Greenberg ME (1996) Calcium influx via the NMDA receptor induces immediate early gene transcription by a MAP kinase/ERK-dependent mechanism. J Neurosci 16:5425-5436.

Xiang H, Kinoshita Y, Knudson CM, Korsmeyer SJ, Schwartzkroin PA, Morrison RS (1998) Bax involvement in p53-mediated neuronal cell death. J Neurosci 18:1363-1373.

Xu B, Doughman Y, Turakhia M, Jiang W, Landsettle CE, Agani FH, Semenza GL, Watanabe M, Yang YC (2007) Partial rescue of defects in Cited2deficient embryos by HIF-1alpha heterozygosity. Dev Biol 301:130-140.

Yin Z, Haynie J, Yang X, Han B, Kiatchoosakun S, Restivo J, Yuan S, Prabhakar NR, Herrup K, Conlon RA, Hoit BD, Watanabe M, Yang YC (2002) The essential role of Cited2, a negative regulator for HIF- $1 \alpha$, in heart development and neurulation. Proc Natl Acad Sci USA 99:10488-10493.

Zhang Y, Qu D, Morris EJ, O'Hare MJ, Callaghan SM, Slack RS, Geller HM, Park DS (2006) The Chk1/Cdc25A pathway as activators of the cell cycle in neuronal death induced by camptothecin. J Neurosci 26:8819-8828.

Zhang YQ, Zhang YN, Wu J, Zhu XY, Xu CQ (2005) Effect of peroxisome proliferation activated receptor-gamma on neuronal cell death induced by hypoxia and ischemia in rats in vitro and in vivo (in Chinese). Zhonghua Yi Xue Za Zhi 85:684-688. 